\title{
Research on the construction of green highway construction technology system
}

\author{
Yucai $\mathrm{Wu}^{1}$, Wei Wang ${ }^{1}$, Dan Wang ${ }^{2 *}$, Zhiqiang $\mathrm{Liu}^{2}$ and Rongrong Qiang ${ }^{2}$ \\ ${ }^{1}$ Guangdong Zihui Expressway Co., Ltd, Guangzhou, Guangdong Province, 510030, China \\ ${ }^{2}$ Research Institute of Highway Ministry of Transport, Beijing, 100086, China
}

\begin{abstract}
Combined with the characteristics and actual needs of expressway project, the demonstration application of green highway construction is mainly carried out from four aspects: "building traffic infrastructure system integrated into natural landscape", "promoting green construction technology of environmental protection, energy saving and high efficiency", "creating tourism type Expressway demonstration project" and "promoting safety intelligent construction and control technology", forming "respecting nature and smooth" The supporting technology system should be established for the green road of "nature, nature protection and integration", and Zihui expressway should be built into a demonstration project of green road in mountain area which is coordinated and integrated with the natural environment.
\end{abstract}

\section{Introduction}

In December 2018, the Department of transportation of Guangdong Province issued the notice on the establishment of the first batch of typical demonstration projects of green highway construction in Guangdong Province (YJJH [2018] No. 3270), which announced the first batch of typical demonstration projects of green highway construction in Guangdong Province and the key demonstration research directions of each project, taking seven highway projects including Zihui project as the first batch of codes And promote the construction of typical demonstration projects of green highway in Guangdong Province. Combined with the long-term development needs of the construction and operation management of the mountain expressway in Guangdong Province, and in accordance with the characteristics and actual needs of Zihui expressway project, the integrated demonstration application of green construction technology is carried out, striving to build a high-quality demonstration project of green Expressway in Guangdong Province and even the whole country.

\section{Project overview}

\subsection{Project overview}

The section from Heyuan Zijin to Huizhou Huiyang of Hehui Dongguan Expressway (hereinafter referred to as "Zihui expressway") is one of the key construction projects in the province, and it is the main traffic artery radiating southeast Jiangxi, northeast Guangdong and Guangdong Hong Kong Macao Bay area. The whole line is $77.41 \mathrm{~km}$ long, with a design speed of $100 \mathrm{~km} / \mathrm{h}$, twoway six lanes, and a subgrade width of $33.5 \mathrm{~m}$. There are 1 super major bridge of $1218.1 \mathrm{~m}, 51$ major bridges of $17282.26 \mathrm{~m}, 7$ interchanges, 1 service area, 1 parking area and 1 management core.

\subsection{Project characters}

(1) The terrain is undulating, with high filling and deep excavation, many high piers and bridges, and high construction safety requirements

The terrain along the project line is mountainous hills in the north, with valley plain, hilly platform in the middle and alluvial plain in the south, with great fluctuation. Among them, there are 81 high fill and steep slope embankment slopes, 85 deep cut slopes, 694 high piers and columns.

(2) The geological conditions are complex and the technology is difficult

The project area is mainly located in the hinterland of Lantang formation, with developed geological structure, complex hydrogeological conditions, poor geological conditions of high slope, bridge foundation and tunnel surrounding rock, difficult treatment and technical difficulties.

(3) There are many environmental sensitive points and high requirements for environmental protection

There are many environmental sensitive points along the project route, such as Zhaoyuan reservoir and other drinking water source protection areas, Guzhai, Tantou Forest Park, etc., which require high environmental security.

(4) Through the north-south traffic artery, landscape and service requirements are high 
The project is an integral part of the traffic artery in the mountainous area connecting the southeast of Jiangxi, the northeast of Guangdong and the Great Bay of Guangdong, Hong Kong and Macao. Along the line, there are good natural landscape resources and cultural landscape resources, with dense vegetation, beautiful scenery, and high requirements for road landscape and service.

\section{Overall thinking planning}

\subsection{Project orientation: excellent demonstration and integration}

\subsection{Planning ideas ("one belt and four themes")}

Based on the development concept of "innovation, coordination, green, opening and sharing", focusing on environmental integration design, environmental protection and green construction, clean and efficient operation, convenient and comfortable service, the overall idea of "one belt and four themes" is established, that is, around "building transportation infrastructure system integrated into natural landscape", "promoting green construction of environmental protection, energy conservation and efficiency" The four themes of "building technology", "building tourism Expressway demonstration project" and "implementing safety intelligent construction and management technology" are to build "linear dynamic highway landscape corridor with regional characteristics", to control resource occupation, reduce energy consumption, reduce pollution discharge, protect ecological environment, serve economic development to the maximum extent, and pay attention to improving construction quality and operation Efficiency, to provide people with safe, comfortable, convenient and beautiful driving environment, and the harmonious coexistence of "quality Zihui scenery" expressway with nature.

\section{Project construction objectives}

Combined with the characteristics of Zihui expressway project and the environment along the line, as well as the national, transportation industry, Guangdong Province's "ecological civilization development", "green highway" and other relevant policy requirements, guided by the concept of green development, with the purpose of building green highway, grasp the linear dynamic landscape characteristics of expressway, and build a highway landscape corridor coordinated by "people + vehicle + road + environment", To establish a typical demonstration project of green highway construction in Guangdong Province and strive to create a high-quality demonstration project of green highway in China.

\section{Main implementation contents}

Combined with the geographical location, regional characteristics, engineering characteristics and construction objectives of Zihui expressway, 10 key tasks and 41 demonstration application technologies are proposed to carry out the green highway construction of Zihui expressway.

\begin{tabular}{|c|c|c|c|}
\hline Order & Theme & Item & Site \\
\hline \multirow{10}{*}{1} & \multirow{10}{*}{$\begin{array}{l}\text { Build traffic } \\
\text { infrastructure } \\
\text { system } \\
\text { integrated with } \\
\text { natural } \\
\text { landscape }\end{array}$} & \multirow{2}{*}{$\begin{array}{l}\text { 1) Technology of } \\
\text { environmental protection route } \\
\text { selection }\end{array}$} & (1) Route selection of water environment sensitive area \\
\hline & & & (2) Comparison and selection of typical road sections \\
\hline & & \multirow{4}{*}{$\begin{array}{l}\text { 2)Technology of land resources } \\
\text { recycling }\end{array}$} & (3) Recycling technology of surface soil resources \\
\hline & & & $\begin{array}{l}\text { (4) Permanent temporary combination technology during } \\
\text { construction }\end{array}$ \\
\hline & & & (5) Land making in roadside filling area \\
\hline & & & (6) Special design of borrow (spoil) area \\
\hline & & \multirow{4}{*}{$\begin{array}{l}\text { 3) Technology of Road } \\
\text { environment restoration }\end{array}$} & (7) Tolerant subgrade design \\
\hline & & & (8) Shallow dish ecological edge \\
\hline & & & (9) Near natural ecological restoration of slope \\
\hline & & & $\begin{array}{l}\text { (10) Collection, treatment, monitoring and early warning system } \\
\text { of bridge deck runoff }\end{array}$ \\
\hline \multirow{5}{*}{2} & \multirow{5}{*}{$\begin{array}{l}\text { Carry out } \\
\text { green } \\
\text { construction } \\
\text { technology of } \\
\text { environmental } \\
\text { protection, } \\
\text { energy saving } \\
\text { and high } \\
\text { efficiency }\end{array}$} & \multirow{5}{*}{$\begin{array}{l}\text { 1) Construction of low carbon } \\
\text { environmental protection tunnel } \\
\text { system }\end{array}$} & (11) Strengthen tunnel construction and excavation control \\
\hline & & & $\begin{array}{l}\text { (12) Utilization technology of waste residue from tunnel } \\
\text { excavation }\end{array}$ \\
\hline & & & $\begin{array}{l}\text { (13) Green environmental protection shotcrete technology for } \\
\text { tunnel }\end{array}$ \\
\hline & & & $\begin{array}{l}\text { (14) Tunnel LED lighting fixture and control system with light } \\
\text { colour double index }\end{array}$ \\
\hline & & & (15) Ventilation system of variable frequency fan in tunnel \\
\hline
\end{tabular}




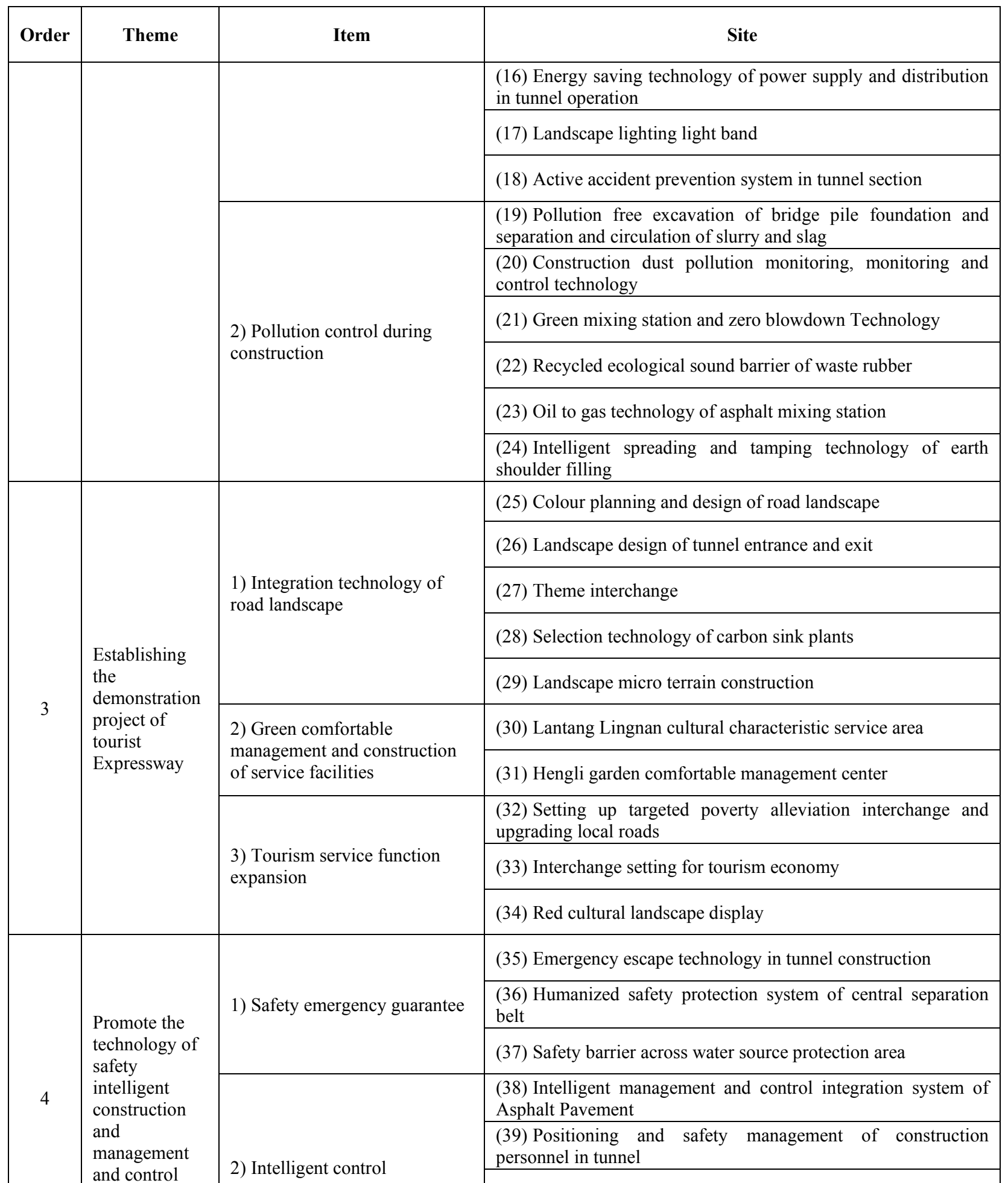

(40) Construction safety digital education and training system

(41) Data acquisition system of concrete mixing station

\section{Conclusion}

On July 4, 2016, the Department of transportation of Guangdong Province held a meeting to accelerate the construction of expressways, which was presided over by Li Jing, Secretary of the Party group of the Department of transportation. The meeting put forward the requirements of "to practice the concept of green transportation development, to achieve the coordination between the construction of expressways and the protection of ecological environment". Since the beginning of planning and design, the project vigorously promotes the construction of green roads, controls the occupation of resources to the maximum extent, reduces energy consumption, reduces pollution emissions, protects the ecological environment, improves the quality of the project and service experience, and combines the long-term development needs of the construction and operation management of mountain highways in 
Guangdong Province, puts forward the construction project of beautiful mountain roads coordinated and integrated with the natural environment Standard, from the fine construction aspect, has carried on the thorough research and the demonstration, has laid the foundation for Guangdong Province green highway, the beautiful highway construction.

\section{Reference}

1. Shang zhonghai. (2008) Research on the establishment technology and Countermeasures of Expressway Green Protection System. Anhui Agricultural Science (12):182-184.

2. Deng guangxi. (2017) Guangdong takes the lead in releasing the technical guide of local green road construction. Transport in Guangdong,

3. Qin xiaochun. (2010) Discussion on the key technology and application of green road construction under the concept of low carbon. Highway transportation technology (Application Technology Edition) (10):316-330.

4. Linan. (2017) Analysis on the technical points of green road construction under the concept of low carbon. Traffic world (8): 136-137.

5. Zhangzhengyi. (2018) Green highway construction and evaluation technology in China. Journal of Chang'an University (NATURAL SCIENCE EDITION), (05):82-92.

6. Luke. (2019) Analysis of green highway design concept and application. Residence, 32: 116

7. Wang Yuwen, Yu Shengjun, Zhu Zuoyun. (2019) Study on evaluation index system of green highway construction. Highway transportation technology (Application Technology Edition), 15: 308-312

8. Wang Chao, Yu Shengjun, Li Jiang. (2019) Study on evaluation index system of green highway design. Highway transportation technology (Application Technology Edition), 15: 305-308

9. Zhan Cheng, Liu Guoliang, Zhou Zhi. (2019) Study on the impact of highway construction on the environment and protection measures. Enterprise science and technology and development, 8: 171172

10. Yuan Jiqiang. (2019) Application of green highway construction concept in expressway design. Tianjin construction technology, 29: 103-104

11. Mo Jianpeng. (2019) Discussion and application of key technologies of green highway [J]. Volkswagen technology,21: 6-8

12. Dong Ruichang. (2019) Application and embodiment of green highway concept in highway construction. Green building materials, 3: 101-104 